\title{
Brain Natriuretic Peptide to Predict Successful Liberation from Mechanical Ventilation in Critically III Patients: a Systematic Review and Meta-Analysis.
}

Jean Deschamps ( $\nabla$ jean3@ualberta.ca )

Faculty of Medicine and Dentistry, University of Alberta https://orcid.org/0000-0002-4872-3334

\section{Sarah K. Andersen}

University of Alberta

Jordan Webber

University of Alberta

Robin Featherstone

University of Alberta

Meghan Sebastianski

University of Alberta

Ben Vandermeer

University of Alberta

Janek Senaratne

University of Alberta

Sean M. Bagshaw

University of Alberta

\section{Research}

Keywords: Natriuretic Peptide, Brain, Respiration, Artificial, Ventilator Weaning, Intensive Care, Critical Care

Posted Date: December 18th, 2019

DOl: https://doi.org/10.21203/rs.2.19088/v1

License: @ (i) This work is licensed under a Creative Commons Attribution 4.0 International License. Read Full License

Version of Record: A version of this preprint was published at Critical Care on May 11th, 2020. See the published version at https://doi.org/10.1186/s13054-020-2823-9. 


\section{Abstract}

Background Predicting successful liberation from mechanical ventilation (MV) in critically ill patients is challenging. Brain natriuretic peptide (BNP) has been proposed to help guide decision-making for readiness to liberate from MV following a spontaneous breathing trial (SBT).

Methods We performed a systematic review and meta-analysis of randomized and prospective observational studies that measured BNP levels at the time of SBT in patients receiving MV. The primary endpoint was successful liberation from MV (absence of re-intubation or non-invasive ventilation at 48h). Statistical analyses include bi-variate and MosesLittenberg models, and DerSimonian-Laird pooling of areas under ROC curve (AUROC).

Results A total of 731 articles were screened. After pre-specified inclusion criteria, 18 adult and 2 pediatric studies were included. The measure of the relative variation of BNP during SBT $(\triangle B N P \%)$ after exclusion of SBT failure by clinical criteria in adults yielded a sensitivity and specificity of 0.889 [0.831-0.929] and 0.828 [0.730-0.896] respectively, with a pooled AUROC of 0.92 [0.88-0.97] for successful liberation from MV. The pooled AUROC for any method of analysis for absolute variation of BNP $(\triangle B N P)$, pre-SBT BNP and post-SBT BNP were 0.89 [0.83-0.95], 0.77 [0.63-0.91], and 0.85 [0.800.90], respectively.

Conclusion The $\triangle B N P$ during a SBT is an accurate incremental tool after SBT success by clinical indices to predict successful liberation from MV in adults. There is insufficient data to support its use as an alternate test to clinical indices of SBT or the use of $\triangle B N P, B N P$-pre and BNP-post as an alternate or incremental test, or in pediatric patients.

\section{Introduction}

Predicting successful liberation from mechanical ventilation (MV) among critically ill patients can be challenging, and there are no standardized methods for assessing readiness for extubation(1). The American College of Chest Physicians/American Thoracic Society (ACCP/ATS) clinical practice guideline (CPG) on liberation from MV suggests a spontaneous breathing trial (SBT) with inspiratory pressure support as the preferred technique; however, this recommendation is based on limited evidence $(1,2)$. Morever, the majority of parameters used to determine whether SBT has been successful are physiologic variables that inconsistently predict successful liberation from MV(3-5). Brain natriuretic peptide (BNP) has been proposed as a novel biomarker to help predict successful liberation from MV. To date, CPGs have not integrated evidence from studies evaluating BNP to predict successful liberation from MV.

BNP is a sensitive marker of myocardial stretch, and its relative change in patients during a SBT has been proposed to provide incremental value to predict successful liberation from $M V(3,5,6)$. BNP is a natriuretic peptide released from cardiomyocytes, measured using one of the two widely available assays (NT-proBNP and BNP). The half-life of BNP is estimated to be 20 minutes, while the half-life of NT-proBNP is estimated at 120 minutes(6). Subclinical congestion and overt pulmonary edema due to changes in left ventricular afterload may be common during SBT. These physiologic changes may be readily detected by measuring relative changes in BNP (7-11). Existing studies have attempted to incorporate BNP at various steps of liberation from MV. The focus of this study will be the use of BNP during a SBT.

Accurate and reliable prediction of extubation failure is clinically important, as extubation failure is known to have greater risk of adverse outcomes including reintubation, nosocomial pneumonia, mortality, and prolonged length of intensive care unit (ICU) stay (2,12-14). Development and validation of rigorous methods incorporating BNP (both BNP and NT-proBNP will be hereto referred to as BNP for the purpose of this manuscript) may augment clinician decision support and rates of successful liberation from MV and also improve patient outcomes. 
The objective of this systematic review is to rigorously evaluate the value of BNP measurement with a SBT as a biomarker to predict liberation from MV among critically ill ICU patients. We hypothesize that BNP would add incremental predictive value for successful liberation from MV compared with standard clinical and biochemical parameters assessed during SBT.

\section{Methods}

The systematic review protocol has been registered with the PROSPERO International Prospective Register of Systematic Reviews (Registration number CRD42018087474 on 2018-02-06), and has been published (2019-02-12)(15). Data for this review was sourced from available published and unpublished studies. As such, no patient-specific primary data was collected and health research ethics approval was not required.

Search strategy and study identification

Search methods

The search strategy was developed and executed by a research librarian (RF) and was peer-reviewed by a second research librarian (Additional file 1) (16-20). We searched electronic databases: Ovid MEDLINE (1946-); Ovid EMBASE (1974-); Wiley Cochrane Library (inception-), including the Cochrane Database of Systematic Reviews (CDSR) and the Cochrane Central Register of Controlled Trials (CENTRAL); and Web of Science Core Collection via Clarivate Analytics (1900-). A combination of the following search themes were used: 1) brain natriuretic peptide, any subtype, and 2) weaning, extubation, or liberation from mechanical ventilation. Results were limited to human studies, published in any language from database inception. Bibliographic records were exported to an EndNote X7 (Thomson Reuters, Philadelphia, Pennsylvania) database for duplicate removal and screening. Additional sources were included in the search strategy. The cited and citing references of included studies and relevant review articles were screened. We also searched trial registry records via ClinicalTrials.gov, and meeting abstracts via the Conference Proceedings Citation Index (Clarivate Analytics). Finally, we identified relevant clinical practice guidelines by searching Choosing Wisely Canada, the National Guidelines Clearinghouse, and TRIP (Turning Research Into Practice) Database.

Study assessment

We included all relevant randomized and pseudo-randomized controlled trials (definedas controlled trials in which patients are randomized according to methods other than concealed random allocation) that measured BNP levels at the time of SBT in patients receiving MV. We also included prospective observational studies that described BNP levels during SBT and assessed for any association with successful extubation rates. We excluded retrospective studies since the timing of BNP measurement relative to SBT was of critical importance for the purpose of this study and may have been prone to bias. We included studies reported as full text, published as an abstract only, and any relevant unpublished data obtained from the authors. There was no language restriction.

Studies were included if they involved patients receiving invasive MV in whom SBT was performed. There were no age restrictions. We included studies with BNP assay of any type (BNP, NT-proBNP, etc.) if performed within 120 minutes of the SBT. There were no restrictions on SBT type. We excluded studies with insufficient data for the outcomes measured when we were unable to obtain the necessary original data from the primary authors.

Page $3 / 21$ 
Eligible articles were identified through two phases. In the first phase, two authors (JD and JW) independently reviewed the titles and abstracts of all retrieved bibliographic records using EndNote X7 (Thomson Reuters, Philadelphia, Pennsylvania) for potential inclusion. In the second phase, full texts of the selected articles were retrieved and two authors (JD and JW) independently reviewed and selected studies that met the inclusion criteria.

\section{Data extraction}

For full-text studies selected for inclusion, relevant information was abstracted using piloted and standardized electronic data forms by two authors independently (JD and SA) (Additional file 2). Abstracted data was then compared between the two authors. Disagreements at every step were resolved through discussion and a third author (SMB) was available for arbitration.

Data analysis and synthesis

The primary endpoint was successful liberation from MV. Successful liberation was defined in accordance with existing literature as the absence of re-inbutation or application of new non-invasive ventilation in the 48 hours following initial extubation(1). We further analyzed any additional data after 48 hours as available in studies. Secondary endpoints initially defined in our protocol could not be analyzed due to insufficient available data.

We examined and compared the characteristics of patients that had failed extubation compared to those that had successful extubations. For binary characteristics (e.g., sex) we computed odds ratio, while for continuous outcomes (e.g., age) we computed mean differences. When we had results from multiple studies they were pooled using a DerSimonian-Laird random effects model. All results were presented with $95 \%$ confidence intervals. Heterogeneity was examined using the I-squared statistic.

Diagnostic accuracy of BNP was measured using sensitivity and specificity. High sensitivity indicates that a low absolute BNP number or low variation of BNP during SBT predicts successful liberation from MV. High specifity indicates that a high absolute BNP number of high variation of BNP during SBT predicts unsuccessful liberation from MV. Where possible, results across studies were simultaneously pooled together using a bi-variate model to create both a joint estimate of sensitivity and specificity (with 95\% confidence regions) as well as hierarchical summary ROC curve (HSROC). For selected subgroup analyses, we were unable to use the bi-variate model due to insufficient studies. In these cases the Moses-Littenberg model was used to estimate a summary ROC curve. When considered sufficiently clinically homogeneous, areas under the ROC curve (AUROC) were pooled when possible using a DerSimonian-Laird random effects model.

Quality assessment 
Quality of each study (JD and SA) was assessed using the QUADAS-2 questionnaire for systematic reviews (22). Ten parameters across four domains (Patient selection, Index test, Reference test and Flow/timing) were analysed independently by two authors (JD and SA) and disagreements resolved through discussion. This was performed in duplicate by two independent reviewers (JD and SA). We applied the strict QUADAS-2 method of assigning low risk or at risk status for each domain. We did not perform a GRADE assessment as described in the protocol, as this was deemed not applicable to this type of research.

\section{Results}

A total of 731 articles were screened, 117 were identified for full-text review, and 20 met the prespecified selection criteria and were included in our analysis (Figure 1, Additional file 3). Of these, there are 18 studies of adult patients and 2 studies of pediatrics patients (Table 1 and 2).

\section{Adult studies}

Of the 18 adult studies, there were 28 individual analyses of BNP relative to SBT. The measures analyzed included: preSBT BNP measures (BNP-pre), post-SBT BNP measures (BNP-post), absolute BNP change during SBT (DBNP), and the relative BNP change during SBT (DBNP\% = [post-SBT BNP - pre-SBT BNP]/pre-SBT BNP). Some studies included more than one measure of BNP. Some studies did not provide a ROC analysis and relied on odds ratio (OR). A subset of studies assessed BNP as an alternative tool to reclassify all patients by including SBT failure in the liberation failure group for the analysis (SBT failure inclusion group). The other subset assessed BNP as an incremental tool to SBT testing by excluding SBT failure from the analysis (SBT failure exclusion group). All studies relied on clinical indices of SBT to determine readiness of extubation, and no decision to extubate was done based on BNP measures.

Patient baseline characteristics, primary diagnoses, acuity scores and ventilatory parameters were reported by status of liberation from MV (Additional file 4). These baseline data points were not classified according to BNP assessment results combined. All studies except one(21) evaluated the first liberation attempt $(n=17)$. All studies observed patients for extubation failure at $48 \mathrm{~h}(\mathrm{n}=18)$, with one study extending observation to 7 days(21). The quality of included studies focused on adults suggested a risk of bias for all but one low-risk study (Table 3 ). The main reasons for risk of bias were patient selection and lack of blinding of the index test and reference test.

\section{Pediatrics studies}

Two studies focused on children (Table 2). One study addressed preterm infants with respiratory distress syndrome, and one study addressed congenital heart surgery patients. Due to the small samples and lack of available data, pooled analysis could not be performed. Both studies were at risk of bias (Table 4).

Meta-analysis 
We performed a single bi-variate estimate of sensitivity and specifity combining DBNP and DBNP\% for studies that both included and excluded patients with SBT failure $(n=5)$. The sensitivity and specificity were $0.889(0.831-0.929)$ and 0.828 (0.730-0.896), respectively (Figure 2). This was further stratified in Moses-Littenberg summary ROC curves for combined DBNP and DBNP\% for studies that included patients with SBT failure and for DBNP\% only for studies that excluded patients with SBT failure (Figure 2 and 3 ).

AUROC were pooled separately for: DBNP\% $\left(n=5,0.92[0.87-0.96], I^{2}=28 \%\right)$ and DBNP $\left(n=3,0.89[0.83-0.95], I^{2}=67 \%\right)$ regardless of inclusion or exclusion of SBT failure in the study analysis (Figure 4); DBNP\% and studies that excluded SBT $\left(n=3,0.92\right.$ [0.88-0.97], $\left.I^{2}=0 \%\right)$ (Figure 5); and BNP-pre $\left(n=4,0.77\right.$ [0.63-0.91], $\left.I^{2}=87 \%\right)$ and BNP-post $(n=4,0.85$ [0.80$0.90], \mathrm{I}^{2}=16 \%$ ) regardless of inclusion or exclusion of SBT failure in the study analysis (Figure 6 ).

No meta-analysis of the specific thresholds of BNP measures could be performed due to insufficient data. A net reclassification index could not be calculated given the limited data assessing BNP measures in SBT failure groups specifically. Only the pediatric study by Zhang et al(22) calculated a NRI of 0.224 for the addition of NT-ProBNP to SBT, supporting an improvement in reclassification.

\section{Discussion}

Key findings

This meta-analysis supports the validity of the relative variation of BNP (DBNP\%) during a SBT as an incremental test after clinical indices to inform the likelihood of successful liberation from MV in adults. This meta-analysis also demonstrated high accuracy using a pooled AUROC of DBNP\% for studies that excluded SBT failure from the liberation failure analysis. Combining absolute and relative variation irrespective of inclusion or exclusion of SBT failure in the liberation failure analysis showed high sensitivity and specificity for predicting successful liberation. The data from DBNP, BNP-pre and BNP-post were currently insufficient to support their additive use in clinical practice.

These are important findings given the limited predictive ability of clinical indices of SBT, which are considered the best available assessment. In studies, SBT misclassified patients in $10-20 \%$ of cases $(14,23)$. While reinsertion of the endotracheal tube was mostly without immediate difficulty, there was greater risk of morbidity and mortality arising from a failed attempt at liberation from MV(1). More accurate alternative tests, such as BNP, may lead to decreased failure of initial attempts, and improved patient outcomes. This possibility has been recognized as early as 2008 in two methods of analysis: as an incremental test to clinical indices during SBT(3), or as an alternate test(24). These two approaches are well represented in the studies in this meta-analysis. The first subset of studies $(n=8)$ included SBT failure in the analysis of the liberation failure group; this in effect assesses BNP as an alternative test to clinical indices SBT. This method has a potential decreased accuracy as compared to excluding those patients that failed the SBT from the analysis, and who may have a higher chance of successful liberation. The second subset of studies ( $n=9)$ excluded SBT failure from the analysis of the liberation failure group: this in effect assesses BNP as an incremental test to clinical indices of SBT. The major benefit in this case is the potential reclassification of patients for whom liberation may have been attempted, but may have failed. This distinction is important to determine the optimal use of BNP in assessment 
for liberation of mechanical ventilation. In our view, the two ways in which SBT failure is incorporated in the analysis should ideally be pooled and analysed separately. However; we expected limited data and pooled them for further analysis as planned in the protocol. Similarly, the different types of BNP measures (DBNP, DeltaBNP\%, BNP-pre and BNPpost) should not be pooled, as some address a variation while others address a point value at a specific time. The only exception in which BNP measures could be pooled would be be DBNP and DBNP\% given the possibility that baseline BNP level may not be relevant in the case of variation during a SBT. The studies that can be pooled together are thus extremely limited.

Most of the data that could be pooled related to variation of BNP during SBT (DBNP and DBNP\%). The analysis described represent the extent of what could be analyzed rigorously. In order to increase the breadth of our analyses, we pooled DBNP and DBNP\% for studies that excluded SBT failure from the analysis of the liberation failure group. The Moses-Littenberg summary ROC analysis showed high accuracy in this case. This summary ROC analysis was mostly driven by DBNP\% (3 out of 4 studies, 148 out of 178 patients). The AUROC of DBNP\% for studies that excluded SBT failure from the analysis of the liberation failure group supports the initial findings and provides numerical evidence of high accuracy (0.92 [0.88-0.97], $\left.\mathrm{I}^{2} \mathrm{0} \%\right)$. This represents the most robust combination of measure and method of analysis obtained from the data.

Unfortunately, the data was insufficient to perform sensitivity and specificity estimates for this specific combination of measure and method of analysis. The closest approximation could be obtained by a bi-variate analysis using pooled data of DBNP and DBNP\%, regardless of inclusion or exclusion of the SBT failure group from the liberation failure analysis. The sensitivity and specificity obtained were high [0.889 (0.831-0.929) and 0.828 (0.730-0.896), respectively]. It is important to note that these results were mostly driven by SBT failure exclusion groups (4 out of 5 studies; 248 out of 278 patients), and DBNP\% (4 out of 5 studies; 178 out of 278 patients). This closely approximates the prior analysis performed on DBNP\% for studies that excluded SBT failure from the analysis. We of course acknowledge that these are not the exact test characteristics for this specific measure and methods of analysis.

There were insufficient studies to analyse DBNP, BNP-pre and BNP-post separately as an incremental test (i.e., excluding SBT failure from the liberation failure analysis) or an alternate test (i.e., including SBT failure from the liberation failure analysis). Pooling studies of both methods of analysis for each BNP measure appears to support a high accuracy in these cases. The obvious limitation is the inability to determine if it is of better use as an incremental or alternate test. Additionally, for BNP-pre and BNP-post, the studies were not reported as strongly positive as DBNP and DBNP\%. Furthermore, it is difficult to determine a superior measure or method, as only two studies compared measurements head-to-head. Both Cheng et al(25) and Martini et al(26) compared DBNP and DBNP\%, and both studies suggest DBNP\% is superior. No other inferences can be made on this point.

From a clinical standpoint, using these measures requires using a specific threshold for dichotomization between likelihood of liberation success versus failure (Table 1). This was determined this through ROC curve analysis of best sensitivity, specificity, positive and negative predictive values and diagnostic accuracy. No pre-specified threshold was studied prospectively in any study. Studies of DBNP\% had the most data with a threshold above $13.4-20 \%(n=4)$ predicting liberation failure, if both BNP types (BNP and NT-ProBNP) were pooled. The other BNP measures had 3 or less 
studies for each BNP type and measure combination (Table 1). Unfortunately, a specific threshold for the BNP measure to discriminate liberation failure from success could not be meta-analysed.

In balance, the analyses performed suggest that BNP performs best if used as a relative BNP variation on a group of patients who have successfully passed a SBT by clinical criteria in adults. The other measures were likely useful, but the data does not allow determination of the best method by which to use them, and they thus cannot be recommended. There is a pauciy data in pediatric cases that limits any conclusion.

Limitations

As described above, the heterogeneity of BNP measurements and approaches for analysis limited our ability to perform pooled analysis; we thus pooled to be able to perform some analyses, acknowledging that this may decrease the reliability and applicability of our results. As we were limited by the data provided, we were unable to stratify by etiology of ICU admission. We opted to combine both general ICU populations and specific ICU subgroups to capture enough data to perform the AUROC analyses. The bi-variate analysis and Moses-Littenberg analyses were unaffected by this choice as all studies included were of a mixed ICU population. We believe that this makes our results more applicable to a general ICU practice. We however cannot reasonably comment on applicability for specific ICU subgroups as each population was represented by a single study.

There are several confounders to the accuracy of BNP testing. Heart disease (and specifically depressed left ventricular ejection fraction) and renal failure can significantly alter BNP kinetics. Unfortunately, these patient characteristics were inconsistently included or excluded across studies. In the case of renal failure, the distinction between acute and chronic renal failure was also poor. In balance, renal function was normal in most studies, and at most mildly impaired in the rest. As for heart disease, the definitions were variable. The etiology of respiratory failure has an impact on the accuracy of BNP: delirium, traumatic brain injury, inability to clear secretions or stridor, amongst others, limit the accuracy of BNP as they may not lead to a change in BNP measurements. A low number of studies that were included in this review attempted to limit this impact by excluding stridor and TBI from the analysis. Unfortunately, capturing clearance of secretions or delirium as the cause of respiratory failure is understanbly difficult and was not done in any study. Another limitation is the lack of studies that directly compared the accuracy of a successful SBT by clinical indices and by BNP measure. In this instance, a patient that has passed a SBT by clinical indices may fail by BNP measure, leading to a delay in extubating a patient that would have succeded. Unfortunately, the relative accuracies were not directly assessed in any study.

Finally, the quality of studies (as defined by QUADAS-2) uniformally ranked as at risk of bias, except for one(27). The main issue was lack of transparency regarding blinding of physicians to the BNP test. In our opinion, this is not a critical flaw, as the decision to extubate patients was most often based on clinical SBT criteria in all studies.

Implications for Clinical, Policy and Research 
Research on mechanical ventilation liberation is complex and would benefit from greater standardization. Successful liberation from mechanical ventilation appears well-defined and this is reflected in the studies collected. Liberation failure, on the other hand, has a variable definition amongst studies, mostly relating to the inclusion or exclusion of SBT failure. Regardless of its importance for applicability of alternative or incremental testing, the terms used require standardization to facilitate research.

Additional data is needed tostrengthen BNP as a liberation tool. We consider that this should take the form of a comparative study of BNP as an alternative or an incremental tool to the clinical indices after an SBT. This study would ideally take the form of an assessment of DBNP and DBNP\%, and compare inclusion versus exclusion of SBT in the analyzed subgroups. This would allow determination of whether BNP is superior to SBT on its own or simply incremental.

The potential benefits of improved tools to inform greater likelihood of success or failure of liberation from MV have farreaching implications. On top of reclassifying individuals after initial assessment with clinical indices, this may allow stratification of the risk of failure. Such a stratification may help better determine targets for optimization (such as further volume de-escalation), better identification of the need for post-extubation therapies (such as high-flow oxygen therapy and BiPAP), and need for prolonged ICU observation. Clinical risk scores on this basis could be developed to aid in management of these patients after extubation.

\section{Conclusion}

The relative variation of BNP during a SBT (DBNP\%) is an accurate and useful incremental tool after SBT success by clinical indices to predict successful liberation from MV. There is insufficient data to support its use as an alternate test to clinical indices of SBT. There is insufficient data to support the use of DBNP, BNP-pre and BNP-post either as an alternate or incremental test. Studies comparing the best use of DBNP\% either as an alternative or incremental tool to clinical indices during SBT represent the next step in research. There is a pauciy data in pediatric cases that limits any conclusion.

\section{Abbreviations}

DBNP\% - Relative variation of BNP during a SBT

MV - Mechanical Ventilation

DBNP - Absolute variation of BNP during a SBT

BNP - Brain natriuretic peptide

SBT - Spontaneous breathing trial

AUROC - Area under ROC curve 
CPG - Clinical practice guideline

ICU - Intensive care unit

HSROC - Hierarchical summary ROC curve

\section{Declarations}

\section{Ethics approval and consent to participate}

Data for this review will be sourced from available published and unpublished studies, if applicable. As such, no patientspecific primary data will be collected, and formal health research ethics approval is not required.

\section{Consent for publication}

Not applicable.

\section{Author's contribution}

JD was responsible for the preparation of the manuscript. SMB, JS, JD and SA were responsible for study selection and data collection. RF developed the search strategy and conducted the search in consultation with JD, JW and SMB. MS provided support for methodology. BV provided support for statistical analysis. SMB conceived the project, and all authors provided critical revision of the protocol and final manuscript. SMB will guarantee the content of the review.

\section{Acknowledgments}

The authors acknowledge the support of Tara Landry MLIS, for her peer-review of the Medline search straegy.

\section{Funding}

SMB is supported by a Canada Research Chair in Critical Care Nephrology. The project was supported by the Alberta Strategy for Patient Oriented Research (SP OR) SUPPORT Unit - Knowledge Translation Platform.

\section{Competing interests}

None declared

\section{Provenance and peer review}

Not commissioned; externally peer reviewed.

\section{Availability of data and materials}

This is an Open Access article distributed in accordance with the Creative Commons Attribution Non Commercial (CC BYNC 4.0) license, which permits other to distributed, remix, adapt, build upon this work non-commercially, and license their derivative works on different terms, provided the original work is properly cited and the use is non-commercial.

\section{Author affiliations}


${ }^{1}$ Department of Critical Care Medicine, Faculty of Medicine and Dentristry, University of Alberta, 8440112 St. NW, Critical Care Medicine 2-124E Clinical Sciences Building, Edmonton, Alberta, T6G 2B7, Canada.

${ }^{2}$ Alberta Strategy for Patient Oriented Research (SPOR) SUPPORT Unit - Knowledge Translation Platform, University of Alberta, 4-472 Edmonton Clinical Health Academy, 11405 - 87 Avenue, Edmonton, Alberta T6G 1C9, Canada.

${ }^{3}$ Alberta Research Center for Health Evidence (ARCHE), University of Alberta, 4-486D Edmonton Clinical Health Academy, 11405 - 87 Avenue, Edmonton, Alberta T6G 1C9, Canada.

${ }^{4}$ Knowledge Translation Platform, Alberta SPOR SUPPORT Unit Department of Pediatrics, University of Alberta, 362-B Heritage Medical Research Centre (HMRC)

${ }^{5}$ Division of Cardiology, Faculty of Medicine and Dentistry, University of Alberta, 8440112 St. NW, Edmonton, Alberta, Canada.

\section{References}

1. Ouellette DR, Patel S, Girard TD, Morris PE, Schmidt GA, Truwit JD, et al. Liberation From Mechanical Ventilation in Critically III Adults: An Official American College of Chest Physicians/American Thoracic Society Clinical Practice Guideline: Inspiratory Pressure Augmentation During Spontaneous Breathing Trials, Protocols Minimizing Sedation, and Noninvasive Ventilation Immediately After Extubation. Vol. 151, Chest. 2017. pp. 166-80.

2. Boles J-M, Bion J, Connors A, Herridge M, Marsh B, Melot C, et al. Weaning from mechanical ventilation. European Respiratory Society; 2007. pp. 1033-56.

3. Zapata L, Vera P, Roglan A, Gich I, Ordonez-Llanos J, Betbesé AJ. B-type natriuretic peptides for prediction and diagnosis of weaning failure from cardiac origin. Intensive Care Med. 2011 Mar;37(3):477-85.

4. Chien J-Y, Lin M-S, Huang Y-CT, Chien Y-F, Yu C-J, Yang P-C. Changes in B-type natriuretic peptide improve weaning outcome predicted by spontaneous breathing trial. Crit Care Med. United States; 2008;36(5):1421-6.

5. Mekontso Dessap A, de Prost N, Girou E, Braconnier F, Lemaire F, Brun-Buisson C, et al. B-type natriuretic peptide and weaning from mechanical ventilation. Intensive Care Med [Internet]. United States; 2006 Aug 29;32(10):1529-36. Available from: http://ovidsp.ovid.com/ovidweb.cgi?T=JS\&PAGE=reference\&D=med5\&NEWS=N\&AN=16941172

6. Zapata L, Vera P, Roglan A, Gich I, Ordonez-Llanos J, Betbesé AJ. B-type natriuretic peptides for prediction and diagnosis of weaning failure from cardiac origin. Intensive Care Med. 2011 Mar;37(3):477-85.

7. Mekontso Dessap A, de Prost N, Girou E, Braconnier F, Lemaire F, Brun-Buisson C, et al. B-type natriuretic peptide and weaning from mechanical ventilation. Intensive Care Med. 2006 Aug 29;32(10):1529-36.

8. Grübler MR, Wigger O, Berger D, Blöchlinger S. Basic concepts of heart-lung interactions during mechanical ventilation. Swiss Med Wkly. 2017 Sep 25;147(3738):w14491.

9. Vieillard-Baron A, Matthay M, Teboul J-L, Bein T, Schultz M, Magder S, et al. Experts' opinion on management of hemodynamics in ARDS patients: focus on the effects of mechanical ventilation. Intensive Care Med. 2016 May;42(5):739-49.

10. Buda AJ, Pinsky MR, Ingels NB, Daughters GT, Stinson EB, Alderman EL. Effect of intrathoracic pressure on left ventricular performance. N Engl J Med. 1979 Aug 30;301(9):453-9.

11. Lemaire F, Teboul J-L, Cinotti L, Giotto G, Abrouk F, Steg G, et al. Acute left ventricular dysfunction during unsuccessful weaning from mechanical ventilation. Anesthesiology. 1988 Aug;69(2):171-9.

12. Capdevila X, Perrigault PF, Ramonatxo M, Roustan JP, Peray P, d'Athis F, et al. Changes in breathing pattern and respiratory muscle performance parameters during difficult weaning. Crit Care Med. 1998 Jan;26(1):79-87. 
13. Menon N, Joffe AM, Deem S, Yanez ND, Grabinsky A, Dagal AH, et al. Occurrence and complications of tracheal reintubation in critically ill adults. Respir Care. 2012 Oct;57(10):1555-63.

14. Epstein SK, Ciubotaru RL, Wong JB. Effect of failed extubation on the outcome of mechanical ventilation. Chest. 1997 Jul;112(1):186-92.

15. Thille AW, Harrois A, Schortgen F, Brun-Buisson C, Brochard L. Outcomes of extubation failure in medical intensive care unit patients. Crit Care Med. 2011 Dec;39(12):2612-8.

16. Moher D, Liberati A, Tetzlaff J, Altman DG, Group TP. Preferred Reporting Items for Systematic Reviews and MetaAnalyses: The PRISMA Statement. PLOS Medicine. Public Library of Science; 2009 Jul 21;6(7):e1000097.

17. Alobaidi R, Morgan C, Basu RK, Stenson E, Featherstone R, Majumdar SR, et al. Associations Between Fluid Balance and Outcomes in Critically III Children: A Protocol for a Systematic Review and Meta-analysis. Can J Kidney Health Dis. 2017;4(8):2054358117692560.

18. McGowan J, Sampson M, Salzwedel DM, Cogo E, Foerster V, Lefebvre C. PRESS Peer Review of Electronic Search Strategies: 2015 Guideline Statement. J Clin Epidemiol. 2016 Jul;75:40-6.

19. Sampson M, McGowan J, Cogo E, Grimshaw J, Moher D, Lefebvre C. An evidence-based practice guideline for the peer review of electronic search strategies. J Clin Epidemiol. 2009 Sep;62(9):944-52.

20. Rewa OG, Villeneuve P-M, Lachance P, Eurich DT, Stelfox HT, Gibney RTN, et al. Quality indicators of continuous renal replacement therapy (CRRT) care in critically ill patients: a systematic review. Intensive Care Med. Springer Berlin Heidelberg; 2017 Jun;43(6):750-63.

21. Lachance P, Villeneuve P-M, Wilson FP, Selby NM, Featherstone R, Rewa O, et al. Impact of e-alert for detection of acute kidney injury on processes of care and outcomes: protocol for a systematic review and meta-analysis. BMJ Open. British Medical Journal Publishing Group; 2016 May 5;6(5):e011152.

22. Whiting PF, Rutjes AWS, Westwood ME, Mallett S, Deeks JJ, Reitsma JB, et al. QUADAS-2: a revised tool for the quality assessment of diagnostic accuracy studies. Annals of Internal Medicine. American College of Physicians; 2011 Oct 18;155(8):529-36.

23. Schünemann HJ, Schünemann AHJ, Oxman AD, Brozek J, Glasziou P, Jaeschke R, et al. Grading quality of evidence and strength of recommendations for diagnostic tests and strategies. BMJ. British Medical Journal Publishing Group; 2008 May 17;336(7653):1106-10.

\section{Tables}




\begin{tabular}{|c|c|c|c|c|c|c|c|c|c|}
\hline Author & $\begin{array}{l}\text { Total } \\
\text { patients }\end{array}$ & Population & $\begin{array}{l}\text { Heart } \\
\text { disease }\end{array}$ & $\begin{array}{l}\text { Renal } \\
\text { failure }\end{array}$ & SBT type & $\begin{array}{l}\text { SBT } \\
\text { failure } \\
\text { status }\end{array}$ & $\begin{array}{l}\text { BNP } \\
\text { type }\end{array}$ & $\begin{array}{l}\text { BNP } \\
\text { measure }\end{array}$ & $\begin{array}{l}\text { Dichotomization } \\
\text { threshold }\end{array}$ \\
\hline $\begin{array}{l}\text { Cheng L } \\
\text { (2015) }\end{array}$ & 56 & $\begin{array}{l}\text { Mixed } \\
\text { population }\end{array}$ & Excluded & Excluded & PS/PEEP & $\begin{array}{l}\text { Exclude } \\
\text { SBT } \\
\text { failure }\end{array}$ & BNP & $\begin{array}{l}\text { DBNP } \\
\text { DBNP\% }\end{array}$ & $\begin{array}{l}80 \mathrm{ng} / \mathrm{L} \\
13.4 \%\end{array}$ \\
\hline $\begin{array}{l}\text { Chien JY } \\
(2008)\end{array}$ & 52 & $\begin{array}{l}\text { Mixed } \\
\text { population }\end{array}$ & Included & Included & T-tube & $\begin{array}{l}\text { Exclude } \\
\text { SBT } \\
\text { failure }\end{array}$ & BNP & DBNP\% & $20 \%$ \\
\hline $\begin{array}{l}\text { Fang M } \\
\text { (2010) }\end{array}$ & 126 & Septic shock & Included & Unclear & PEEP & $\begin{array}{l}\text { Include } \\
\text { SBT } \\
\text { failure }\end{array}$ & $\begin{array}{l}\text { NT- } \\
\text { proBNP } \\
\text { log NT- } \\
\text { proBNP }\end{array}$ & $\begin{array}{l}\text { Pre-SBT } \\
\text { BNP }\end{array}$ & $3914.5 \mathrm{ng} / \mathrm{L}$ \\
\hline $\begin{array}{l}\text { Fang M } \\
\text { (2013) }\end{array}$ & 52 & Septic shock & Included & Unclear & PEEP & $\begin{array}{l}\text { Include } \\
\text { SBT } \\
\text { failure }\end{array}$ & $\begin{array}{l}\text { NT- } \\
\text { proBNP } \\
\text { log NT- } \\
\text { proBNP }\end{array}$ & $\begin{array}{l}\text { Pre-SBT } \\
\text { BNP }\end{array}$ & $\mathrm{N} / \mathrm{A}$ \\
\hline $\begin{array}{l}\text { Farghaly } \\
\text { S (2015) }\end{array}$ & 30 & $\begin{array}{l}\text { Chronic } \\
\text { respiratory } \\
\text { failure }\end{array}$ & Excluded & Excluded & PS/PEEP & $\begin{array}{l}\text { Include } \\
\text { SBT } \\
\text { failure }\end{array}$ & BNP & $\begin{array}{l}\text { Post- } \\
\text { SBT } \\
\text { BNP } \\
\text { DBNP\% }\end{array}$ & $\begin{array}{l}164 \mathrm{ng} / \mathrm{L} \\
14.9 \%\end{array}$ \\
\hline $\begin{array}{l}\text { Haji K } \\
(2018)\end{array}$ & 53 & $\begin{array}{l}\text { Mixed } \\
\text { population }\end{array}$ & Included & Included & PEEP & $\begin{array}{l}\text { Include } \\
\text { SBT } \\
\text { failure }\end{array}$ & $\mathrm{BNP}$ & $\begin{array}{l}\text { BNP- } \\
\text { post }\end{array}$ & N/A \\
\hline $\begin{array}{l}\text { Hersh D } \\
(2004)\end{array}$ & 23 & $\begin{array}{l}\text { Mixed } \\
\text { population }\end{array}$ & Unclear & Unclear & Unclear & $\begin{array}{l}\text { Exclude } \\
\text { SBT } \\
\text { failure }\end{array}$ & $\mathrm{BNP}$ & $\begin{array}{l}\text { Pre-SBT } \\
\text { BNP }\end{array}$ & N/A \\
\hline $\begin{array}{l}\text { Konomi I } \\
(2016)\end{array}$ & 42 & $\begin{array}{l}\text { Mixed } \\
\text { population }\end{array}$ & $\begin{array}{l}\text { Included } \\
\text { (except } \\
\text { valvulopathy) }\end{array}$ & Included & T-piece & $\begin{array}{l}\text { Include } \\
\text { SBT } \\
\text { failure }\end{array}$ & $\mathrm{BNP}$ & $\begin{array}{l}\text { Pre-SBT } \\
\text { BNP }\end{array}$ & N/A \\
\hline $\begin{array}{l}\text { Lara TM } \\
\text { (2013) }\end{array}$ & 101 & $\begin{array}{l}\text { Elective } \\
\text { CABG with } \\
\text { CPB }\end{array}$ & Included & $\begin{array}{l}\text { Excluded } \\
\text { (CKD) }\end{array}$ & Unclear & $\begin{array}{l}\text { Include } \\
\text { SBT } \\
\text { failure }\end{array}$ & BNP & $\begin{array}{l}\text { Post- } \\
\text { SBT } \\
\text { BNP }\end{array}$ & $299 \mathrm{ng} / \mathrm{L}$ \\
\hline $\begin{array}{l}\text { Luo L } \\
\text { (2017) }\end{array}$ & 60 & $\begin{array}{l}\text { Mixed } \\
\text { population } \\
\text { (failed } \\
\text { extubation } \\
\text { once) }\end{array}$ & $\begin{array}{l}\text { Included } \\
\text { (except MV } \\
\text { disease) }\end{array}$ & Included & T-tube & $\begin{array}{l}\text { Exclude } \\
\text { SBT } \\
\text { failure }\end{array}$ & $\begin{array}{l}\text { NT- } \\
\text { proBNP }\end{array}$ & $\begin{array}{l}\text { Post- } \\
\text { SBT } \\
\text { BNP }\end{array}$ & N/A \\
\hline $\begin{array}{l}\text { Ma G } \\
(2013)\end{array}$ & 29 & $\begin{array}{l}\text { Cancer } \\
\text { patients with } \\
\text { pulmonary } \\
\text { complications } \\
\text { undergoing } \\
\text { noncardiac } \\
\text { major } \\
\text { surgery }\end{array}$ & Excluded & Excluded & T-tube & $\begin{array}{l}\text { Include } \\
\text { SBT } \\
\text { failure }\end{array}$ & $\begin{array}{l}\text { NT- } \\
\text { proBNP }\end{array}$ & $\begin{array}{l}\text { Post- } \\
\text { SBT } \\
\text { BNP }\end{array}$ & $448 \mathrm{ng} / \mathrm{L}$ \\
\hline $\begin{array}{l}\text { Maraghi } \\
\text { SE } \\
(2014)\end{array}$ & 40 & $\begin{array}{l}\text { Mixed } \\
\text { population }\end{array}$ & Excluded & Excluded & T-tube & $\begin{array}{l}\text { Exclude } \\
\text { SBT } \\
\text { failure }\end{array}$ & BNP & DBNP\% & $20 \%$ \\
\hline $\begin{array}{l}\text { Martini A } \\
\text { (2011) }\end{array}$ & 98 & Unclear & Included & Unclear & Unclear & Unclear & $\begin{array}{l}\text { NT- } \\
\text { proBNP }\end{array}$ & DBNP & N/A \\
\hline $\begin{array}{l}\text { Mekontso } \\
\text { Dessap A } \\
\text { (2006) }\end{array}$ & 102 & $\begin{array}{l}\text { Mixed } \\
\text { population }\end{array}$ & Included & Excluded & $\begin{array}{l}\text { T-Piece } \\
\text { PS/PEEP }\end{array}$ & $\begin{array}{l}\text { Include } \\
\text { SBT } \\
\text { failure }\end{array}$ & BNP & $\begin{array}{l}\text { Pre-SBT } \\
\text { BNP } \\
\text { DBNP }\end{array}$ & $\mathrm{N} / \mathrm{A}$ \\
\hline $\begin{array}{l}\text { Ouanes- } \\
\text { Besbes L } \\
\text { (2012) }\end{array}$ & 143 & $\begin{array}{l}\text { Mixed } \\
\text { population }\end{array}$ & Included & $\begin{array}{l}\text { Excluded } \\
\text { (any) }\end{array}$ & T-tube & $\begin{array}{l}\text { Exclude } \\
\text { SBT } \\
\text { failure }\end{array}$ & $\begin{array}{l}\text { NT- } \\
\text { proBNP }\end{array}$ & $\begin{array}{l}\text { Pre-SBT } \\
\text { BNP }\end{array}$ & $\begin{array}{l}\text { Rule-in: } 2000 \\
\text { ng/L } \\
\text { Rule-out: } 1000 \\
\text { ng/L }\end{array}$ \\
\hline $\begin{array}{l}\text { Soummer } \\
\text { A (2012) }\end{array}$ & 100 & $\begin{array}{l}\text { Mixed } \\
\text { population }\end{array}$ & Included & Included & T-tube & $\begin{array}{l}\text { Exclude } \\
\text { SBT }\end{array}$ & BNP & $\begin{array}{l}\text { Post- } \\
\text { SBT }\end{array}$ & $267 \mathrm{ng} / \mathrm{L}$ \\
\hline
\end{tabular}




\begin{tabular}{|c|c|c|c|c|c|c|c|c|c|}
\hline & & & & & & failure & & BNP & \\
\hline $\begin{array}{l}\text { Wang YT } \\
\text { (2016) }\end{array}$ & 82 & $\begin{array}{l}\text { Mixed } \\
\text { population }\end{array}$ & Excluded & Excluded & PEEP & $\begin{array}{l}\text { Exclude } \\
\text { SBT } \\
\text { failure }\end{array}$ & $\begin{array}{l}\text { NT- } \\
\text { proBNP }\end{array}$ & $\begin{array}{l}\text { Post- } \\
\text { SBT } \\
\text { BNP }\end{array}$ & $\mathrm{N} / \mathrm{A}$ \\
\hline $\begin{array}{l}\text { Zapata L } \\
\text { (2011) }\end{array}$ & 100 & $\begin{array}{l}\text { Mixed } \\
\text { population }\end{array}$ & Included & Included & T-tube & $\begin{array}{l}\text { Exclude } \\
\text { SBT } \\
\text { failure }\end{array}$ & $\begin{array}{l}\text { BNP } \\
\text { NT- } \\
\text { proBNP }\end{array}$ & $\begin{array}{l}\text { Pre-SBT } \\
\text { BNP } \\
\text { DBNP }\end{array}$ & $\begin{array}{l}\text { BNP - } 263 \text { ng/L; } \\
\text { NT-ProBNP - } \\
1343 \text { ng/L } \\
\text { DBNP - } 48 \text { ng/L } \\
\text { DNT-ProBNP } \\
\text {-21 ng/L }\end{array}$ \\
\hline
\end{tabular}

Table 1-Included adult studies

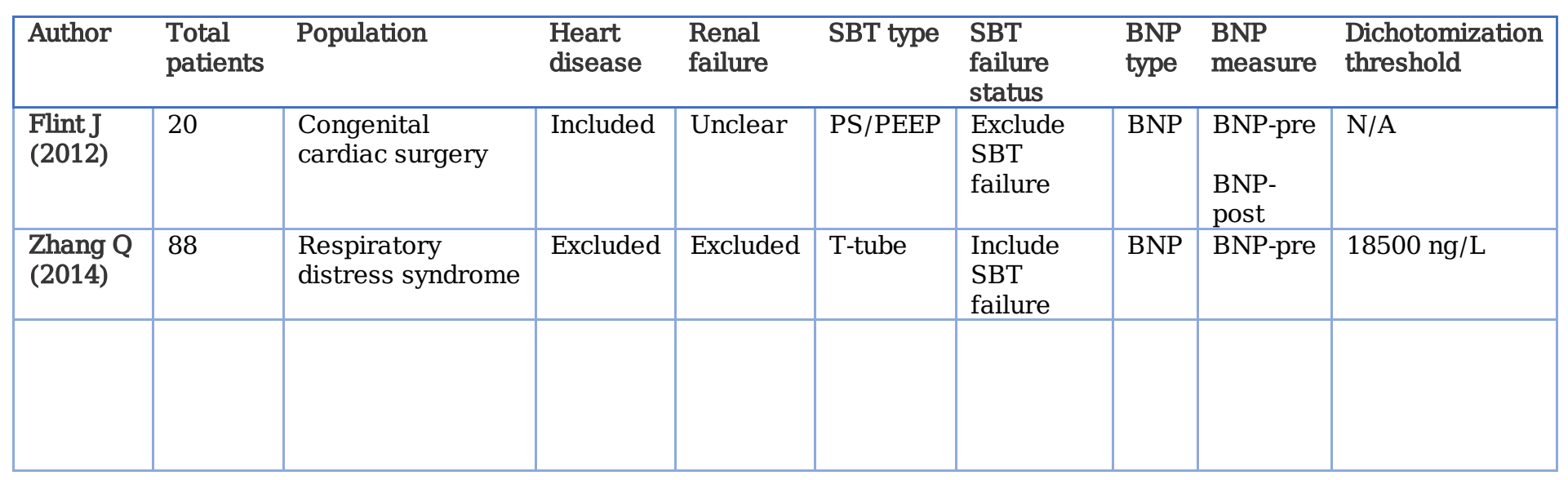

Table 2 - Included pediatric studies

Table 3 - Quality of adult studies 


\begin{tabular}{|c|c|c|c|c|c|c|c|c|c|}
\hline \multicolumn{5}{|c|}{ Risk of Bias } & \multicolumn{5}{|c|}{ Applicability } \\
\hline Authors & $\begin{array}{l}\text { Patient } \\
\text { selection }\end{array}$ & $\begin{array}{l}\text { Index } \\
\text { test }\end{array}$ & $\begin{array}{l}\text { Reference } \\
\text { test }\end{array}$ & Flow/Timing & $\begin{array}{l}\text { Patient } \\
\text { selection }\end{array}$ & $\begin{array}{l}\text { Index } \\
\text { Test }\end{array}$ & $\begin{array}{l}\text { Reference } \\
\text { test }\end{array}$ & $\begin{array}{l}\text { Total } \\
\text { quality }\end{array}$ & Applicability \\
\hline Cheng L (2015) & At risk & $\begin{array}{l}\text { At } \\
\text { risk }\end{array}$ & At risk & Low & No & No & No & At risk & $\begin{array}{l}\text { No } \\
\text { concerns }\end{array}$ \\
\hline Chien JY (2008) & At risk & $\begin{array}{l}\text { At } \\
\text { risk }\end{array}$ & At risk & Low & No & No & No & At risk & $\begin{array}{l}\text { No } \\
\text { concerns }\end{array}$ \\
\hline Chien JY (2008) & At risk & Low & At risk & Low & No & No & No & At risk & $\begin{array}{l}\text { No } \\
\text { concerns }\end{array}$ \\
\hline Fang M (2013) & At risk & $\begin{array}{l}\text { At } \\
\text { risk }\end{array}$ & At risk & Low & No & No & No & At risk & $\begin{array}{l}\text { No } \\
\text { concerns }\end{array}$ \\
\hline Fang M (2010) & At risk & $\begin{array}{l}\text { At } \\
\text { risk }\end{array}$ & At risk & Low & No & No & No & At risk & $\begin{array}{l}\text { No } \\
\text { concerns }\end{array}$ \\
\hline $\begin{array}{l}\text { Farghaly S } \\
\text { (2015) }\end{array}$ & At risk & $\begin{array}{l}\text { At } \\
\text { risk }\end{array}$ & At risk & Low & No & No & No & At risk & $\begin{array}{l}\text { No } \\
\text { concerns }\end{array}$ \\
\hline Haji K (2018) & At risk & $\begin{array}{l}\text { At } \\
\text { risk }\end{array}$ & At risk & Low & No & No & No & At risk & $\begin{array}{l}\text { No } \\
\text { concerns }\end{array}$ \\
\hline Hersh D (2004) & At risk & $\begin{array}{l}\text { At } \\
\text { risk }\end{array}$ & At risk & At risk & No & No & No & At risk & $\begin{array}{l}\text { No } \\
\text { concerns }\end{array}$ \\
\hline Konomi I (2016) & Low & $\begin{array}{l}\text { At } \\
\text { risk }\end{array}$ & Low & Low & No & No & No & At risk & $\begin{array}{l}\text { No } \\
\text { concerns }\end{array}$ \\
\hline Lara TM (2013) & Low & $\begin{array}{l}\text { At } \\
\text { risk }\end{array}$ & At risk & Low & No & No & No & At risk & $\begin{array}{l}\text { No } \\
\text { concerns }\end{array}$ \\
\hline Luo L (2017) & At risk & $\begin{array}{l}\text { At } \\
\text { risk }\end{array}$ & At risk & Low & No & No & No & At risk & $\begin{array}{l}\text { No } \\
\text { concerns }\end{array}$ \\
\hline Ma G (2013) & Low & Low & Low & Low & No & No & No & At risk & $\begin{array}{l}\text { No } \\
\text { concerns }\end{array}$ \\
\hline $\begin{array}{l}\text { Maraghi SE } \\
\text { (2014) }\end{array}$ & Low & $\begin{array}{l}\text { At } \\
\text { risk }\end{array}$ & At risk & Low & No & No & No & At risk & $\begin{array}{l}\text { No } \\
\text { concerns }\end{array}$ \\
\hline $\begin{array}{l}\text { Martini A } \\
\text { (2011) }\end{array}$ & At risk & $\begin{array}{l}\text { At } \\
\text { risk }\end{array}$ & At risk & At risk & No & No & No & At risk & $\begin{array}{l}\text { No } \\
\text { concerns }\end{array}$ \\
\hline $\begin{array}{l}\text { Mekontso } \\
\text { Dessap A } \\
\text { (2006) }\end{array}$ & Low & $\begin{array}{l}\text { At } \\
\text { risk }\end{array}$ & Low & Low & No & No & No & At risk & $\begin{array}{l}\text { No } \\
\text { concerns }\end{array}$ \\
\hline $\begin{array}{l}\text { Ouanes-Besbes } \\
\text { L (2012) }\end{array}$ & Low & $\begin{array}{l}\text { At } \\
\text { risk }\end{array}$ & At risk & Low & No & No & No & At risk & $\begin{array}{l}\text { No } \\
\text { concerns }\end{array}$ \\
\hline $\begin{array}{l}\text { Soummer A } \\
\text { (2012) }\end{array}$ & Low & Low & Low & Low & No & No & No & Low & $\begin{array}{l}\text { No } \\
\text { concerns }\end{array}$ \\
\hline Wang YT (2016) & Low & $\begin{array}{l}\text { At } \\
\text { risk }\end{array}$ & At risk & At risk & No & No & No & At risk & $\begin{array}{l}\text { No } \\
\text { concerns }\end{array}$ \\
\hline Zapata L (2011) & At risk & $\begin{array}{l}\text { At } \\
\text { risk }\end{array}$ & Low & Low & No & No & No & At risk & $\begin{array}{l}\text { No } \\
\text { concerns }\end{array}$ \\
\hline Flint J (2012) & At risk & $\begin{array}{l}\text { At } \\
\text { risk }\end{array}$ & Low & At risk & No & No & No & At risk & $\begin{array}{l}\text { No } \\
\text { concerns }\end{array}$ \\
\hline Zhang Q (2014) & At risk & $\begin{array}{l}\text { At } \\
\text { risk }\end{array}$ & Low & At risk & No & No & No & At risk & $\begin{array}{l}\text { No } \\
\text { concerns }\end{array}$ \\
\hline
\end{tabular}

Table 4- Quality of pediatric studies

\begin{tabular}{|c|c|c|c|c|c|c|c|c|c|}
\hline \multicolumn{5}{|c|}{ Risk of bias } & \multicolumn{5}{|c|}{ Applicability } \\
\hline Authors & $\begin{array}{l}\text { Patient } \\
\text { selection }\end{array}$ & $\begin{array}{l}\text { Index } \\
\text { test }\end{array}$ & $\begin{array}{l}\text { Reference } \\
\text { test }\end{array}$ & Flow/Timing & $\begin{array}{l}\text { Patient } \\
\text { selection }\end{array}$ & $\begin{array}{l}\text { Index } \\
\text { Test }\end{array}$ & $\begin{array}{l}\text { Reference } \\
\text { test }\end{array}$ & $\begin{array}{l}\text { Total } \\
\text { quality }\end{array}$ & Applicability \\
\hline $\begin{array}{l}\text { Flint J } \\
\text { (2012) }\end{array}$ & At risk & Low & Low & Low & Low & Low & Low & At risk & $\begin{array}{l}\text { No } \\
\text { concerns }\end{array}$ \\
\hline $\begin{array}{l}\text { Zhang Q } \\
\text { (2014) }\end{array}$ & At risk & At risk & At risk & Low & Low & Low & Low & At risk & $\begin{array}{l}\text { No } \\
\text { concerns }\end{array}$ \\
\hline
\end{tabular}


Figure 1-Flow diagram for study assessment

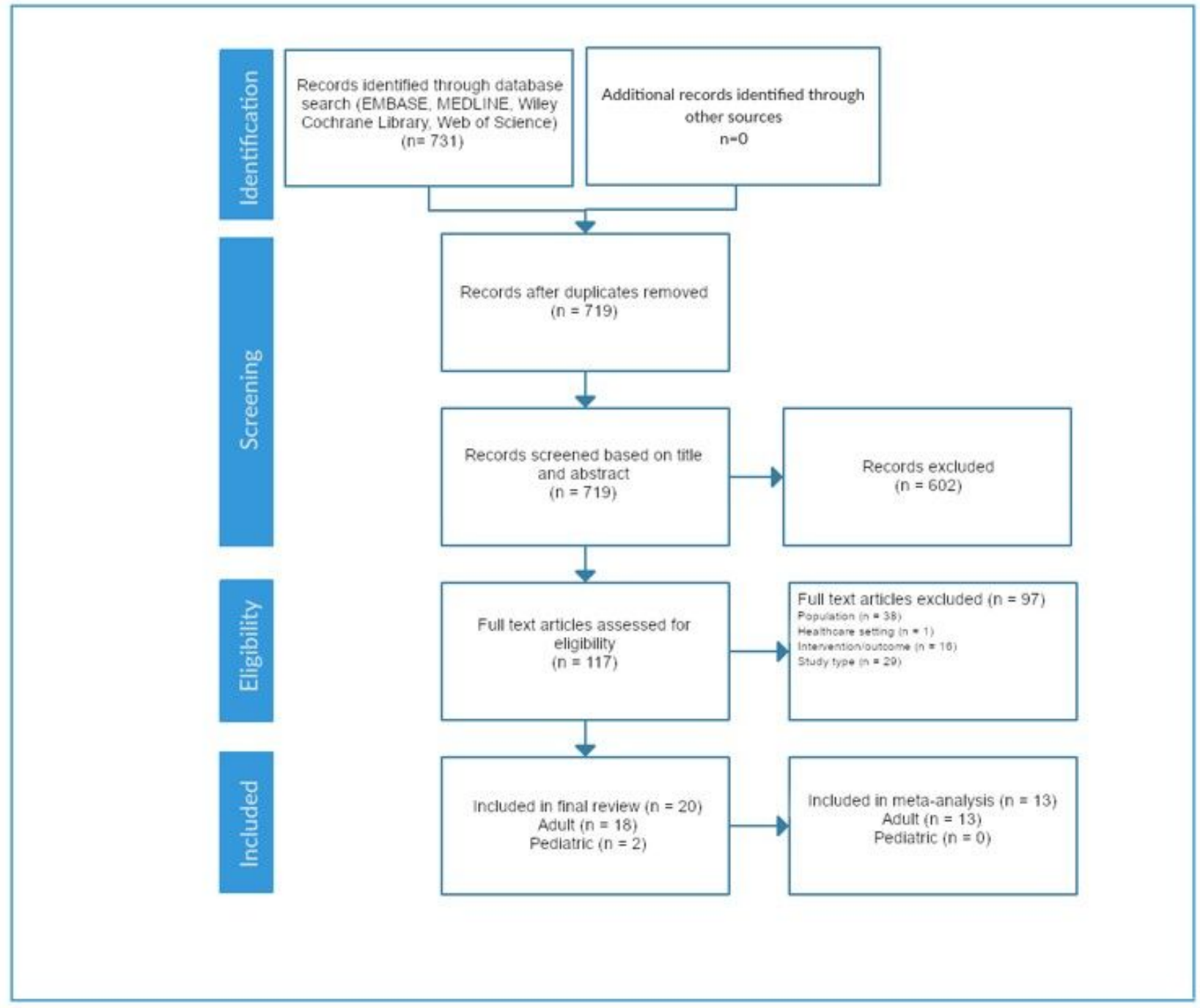

Figure 1

Flow diagram for study assessment 
Figure 2 - Bi-variate estimate of sensitivity and specificity for pooled DeltaBNP and DeltaBNP\% for studies that included SBT failure and studies that excluded SBT failure from analysis.

$\begin{array}{lrrrrrrr}\text { Study } & \text { TP } & \text { FP } & \text { FN } & \text { TN } & \text { Sensitivity }(95 \% \mathrm{Cl}) & \text { Specificity }(95 \% \mathrm{Cl}) & \text { Sensitivity }(95 \% \mathrm{Cl}) \\ \text { Cheng } 2015 & 28 & 4 & 5 & 19 & 0.85[0.68,0.95] & 0.83[0.61,0.95] & \text { Specificity }(95 \% \mathrm{Cl}) \\ \text { Chien 2008 } & 30 & 1 & 3 & 7 & 0.91[0.76,0.98] & 0.88[0.47,1.00] \\ \text { Farghaly 2015 } & 13 & 5 & 3 & 9 & 0.81[0.54,0.96] & 0.64[0.35,0.87] \\ \text { Maraghi 2014 } & 30 & 1 & 3 & 6 & 0.91[0.76,0.98] & 0.86[0.42,1.00] & \\ \text { Zapata 2011 } & 53 & 5 & 5 & 37 & 0.91[0.81,0.97] & 0.88[0.74,0.96] & \end{array}$

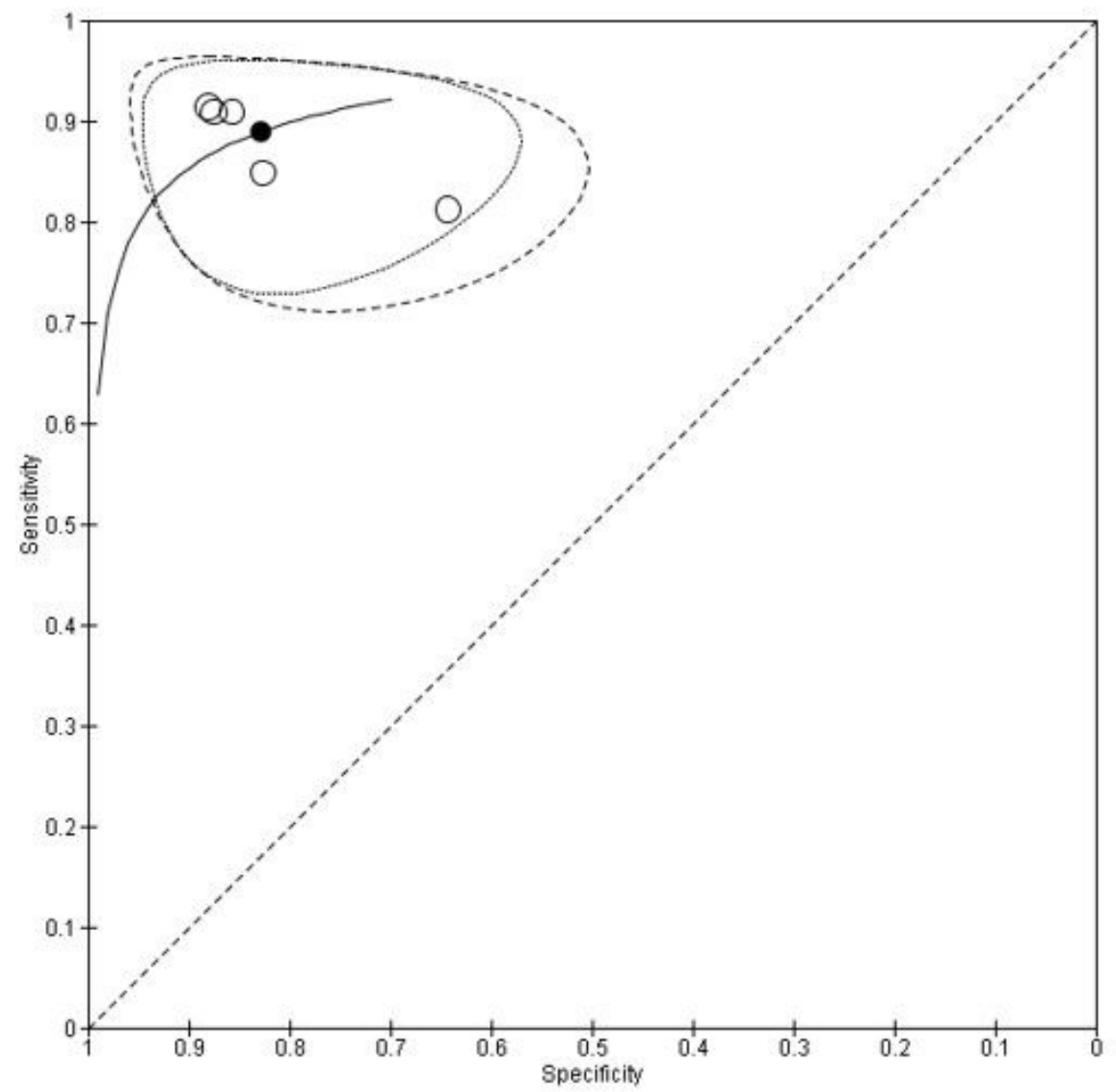

$\mathrm{Bi}$-variate estimate of sensitivity and specificity: Sens: $0.889(0.831,0.929) \mathrm{Spec}: 0.828(0.730,0.896)$

\section{Figure 2}

Bi-variate estimate of sensitivity and specificity for pooled DeltaBNP and DeltaBNP\% for studies that included SBT failure and studies that excluded SBT failure from analysis. 
Figure 3-Moges-Littenberg analysis of pooled DeltaBNP and DeltaBNP\% for studies that that excluded SBT

failure from analysis.
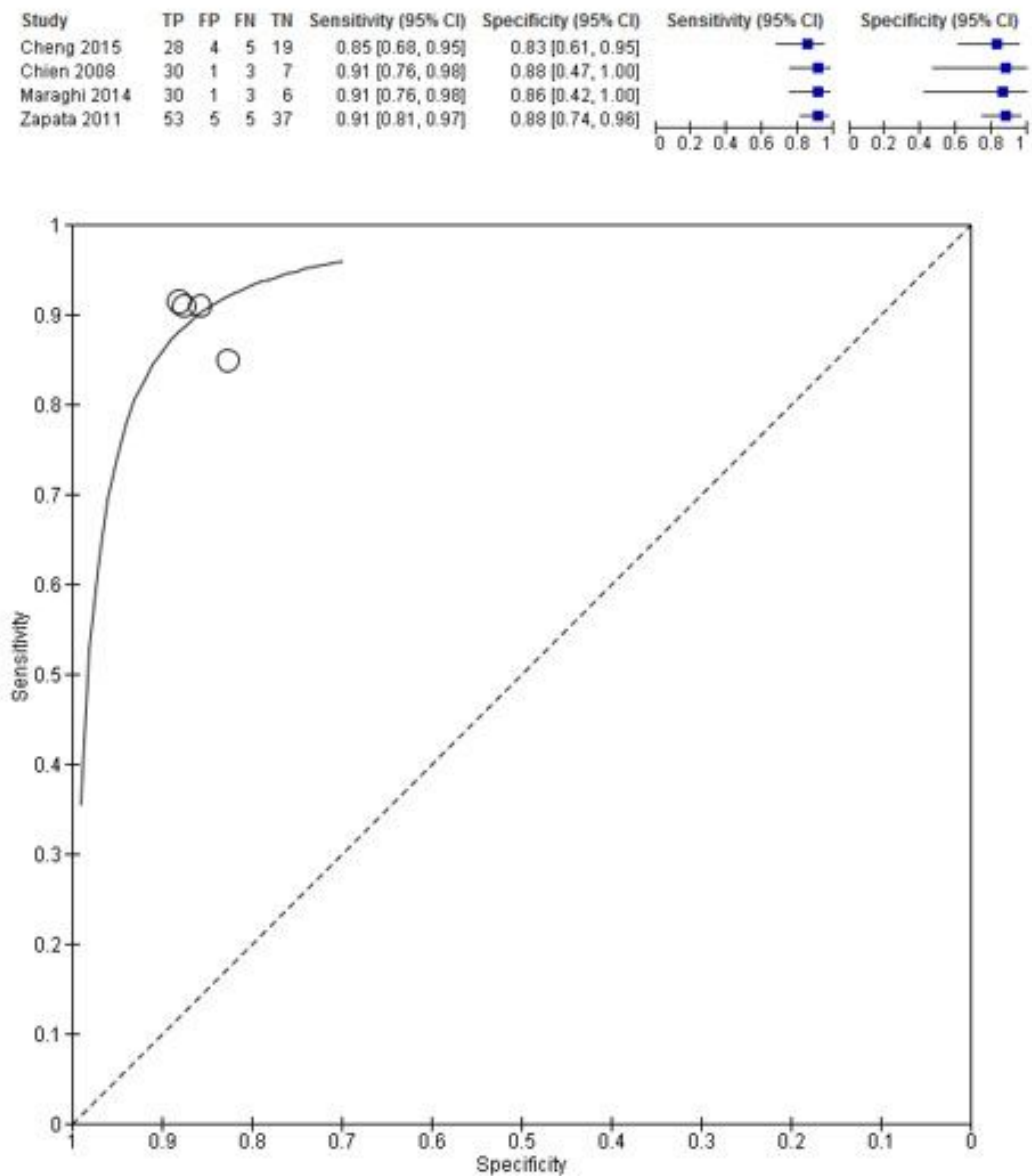

Figure 3

Moses-Littenberg analysis of pooled DeltaBNP and DeltaBNP\% for studies that that excluded SBT failure from analysis. 
Figure 4 - Pooled diagnostic ROC DeltaBNP\% and DeltaBNP for studies that included SBT failure and studies that excluded SBT failure from analysis.

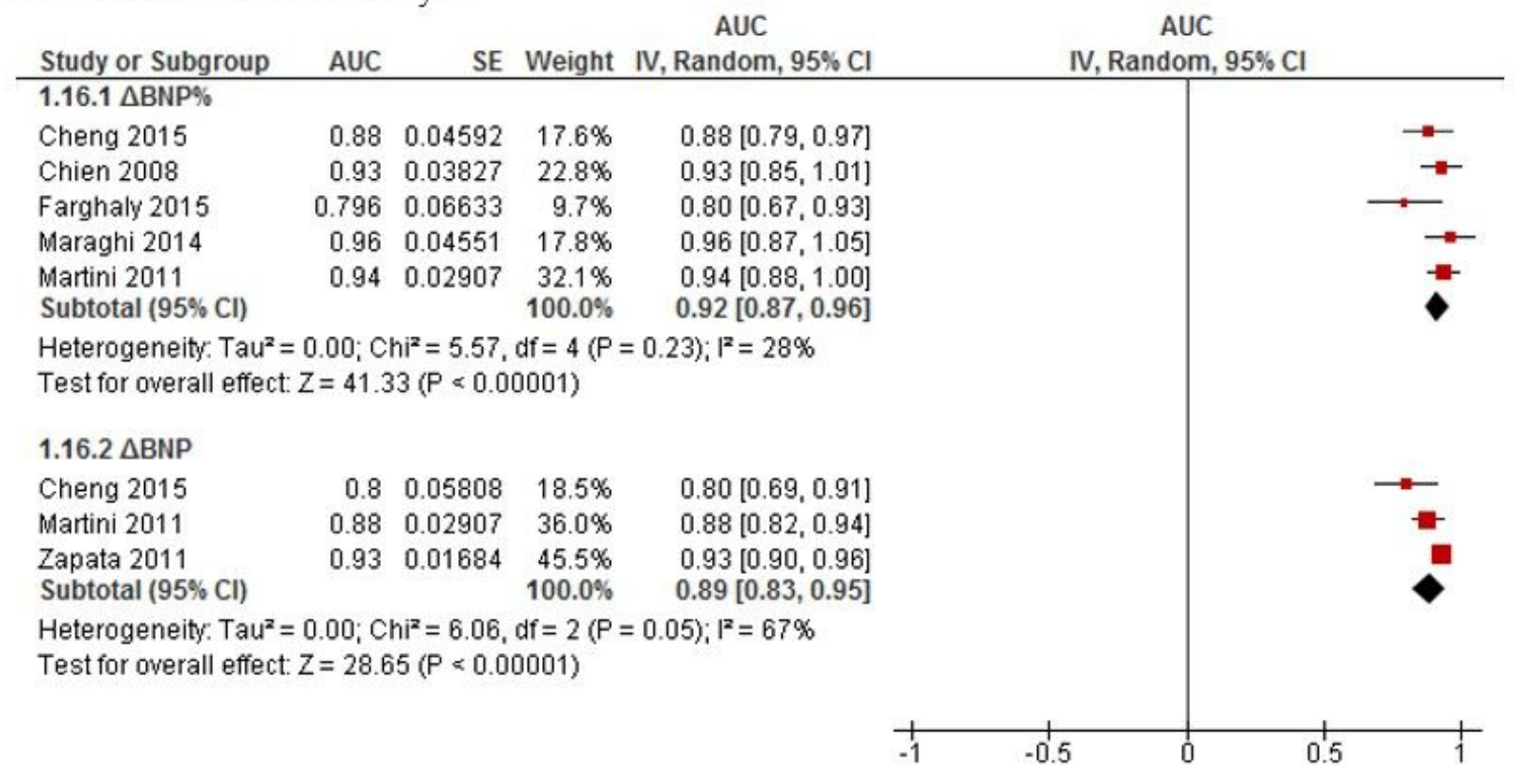

Test for subaroup differences: $\mathrm{Chi}^{2}=0.57, \mathrm{df}=1(\mathrm{P}=0.45) . \mathrm{I}^{2}=0 \%$

\section{Figure 4}

Pooled diagnostic ROC DeltaBNP\% and DeltaBNP for studies that included SBT failure and studies that excluded SBT failure from analysis. 
Figure 5 - Pooled diagnostic ROC of DeltaBNP\% and DeltaBNP for studies that excluded SBT failure from analysis.

\begin{tabular}{lcccc|c} 
Study or Subgroup & AUC & SE & Weight & AU, Random, 95\% Cl & AUC \\
IV, Random, 95\% Cl
\end{tabular}

Test for subaroup differences: $\mathrm{Chi}^{2}=0.48, \mathrm{df}=1(\mathrm{P}=0.49) . \mathrm{I}^{2}=0 \%$

\section{Figure 5}

Pooled diagnostic ROC of DeltaBNP\% and DeltaBNP for studies that excluded SBT failure from analysis. 
Figure 6-Pooled diagnostic ROC of BNP-Pre or BNP-post for studies that included SBT failure and excluded SBT failure from analysis.

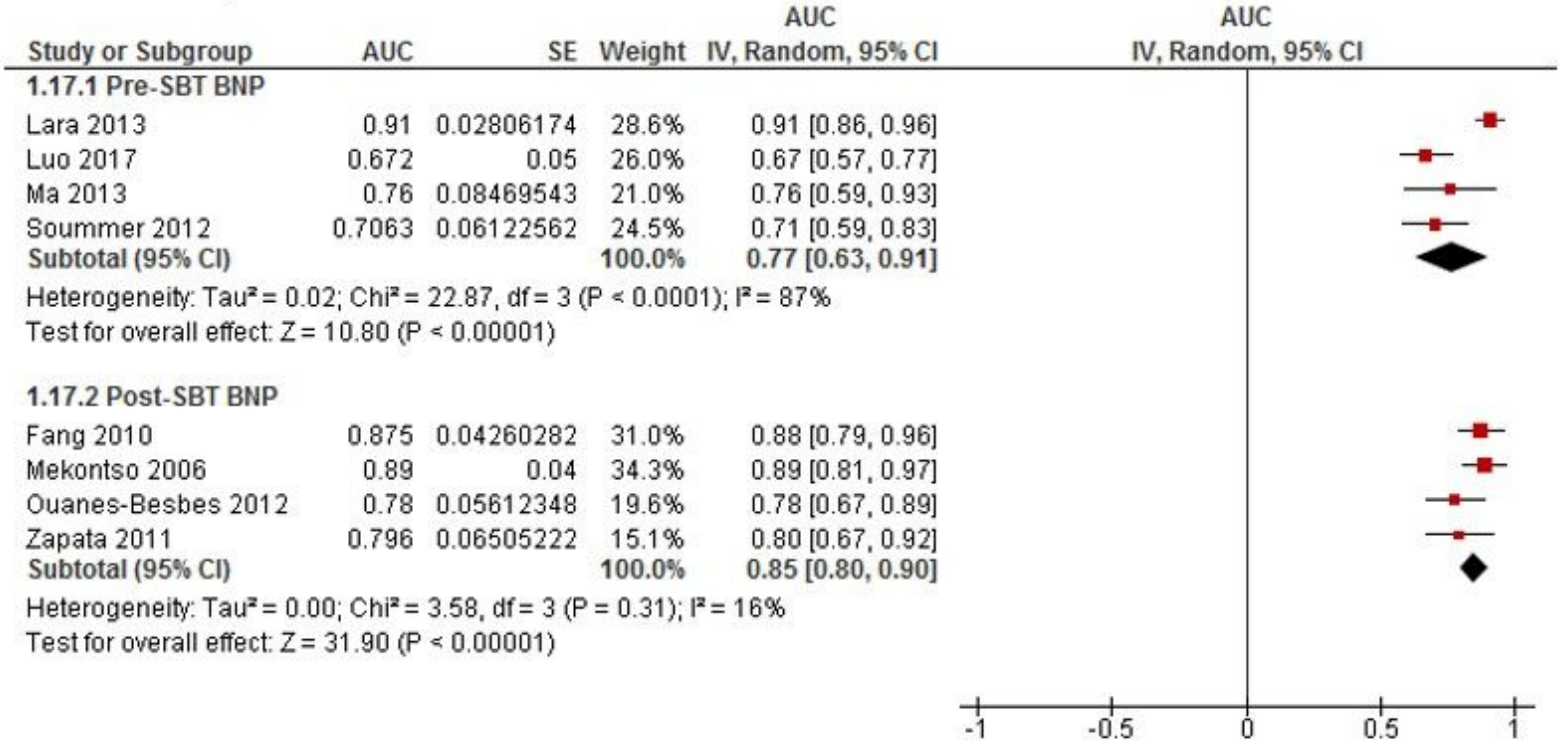

Test for subqroup differences: $\mathrm{Ch}^{2}=1.19, \mathrm{df}=1(\mathrm{P}=0.27) \cdot \mathrm{I}^{2}=16.2 \%$

\section{Figure 6}

Pooled diagnostic ROC of BNP-Pre or BNP-post for studies that included SBT failure and excluded SBT failure from analysis.

\section{Supplementary Files}

This is a list of supplementary files associated with this preprint. Click to download.

- Additionalfile4.docx

- Additionalfile3.docx

- Additionalfile1.docx

- Additionalfile2.docx 